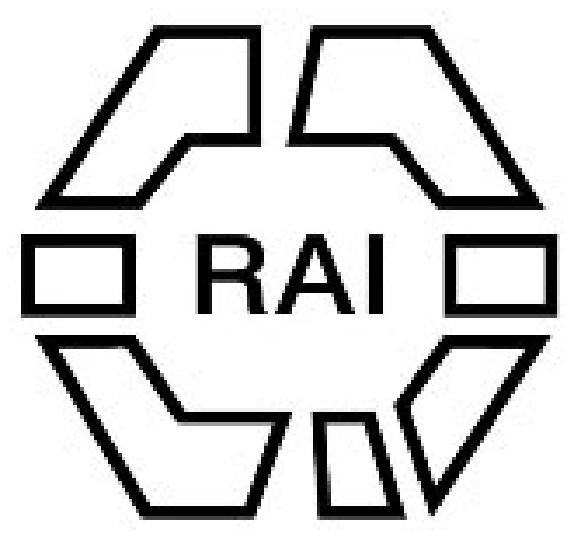

Note upon an Implement of Palæolithic Type from the Victoria Falls, Zambesi Author(s): H. Balfour

Source: The Journal of the Anthropological Institute of Great Britain and Ireland, Vol. 36 (Jan. - Jun., 1906), pp. 170-171

Published by: Royal Anthropological Institute of Great Britain and Ireland

Stable URL: http://www.jstor.org/stable/1193254

Accessed: 14/06/2014 09:33

Your use of the JSTOR archive indicates your acceptance of the Terms \& Conditions of Use, available at http://www.jstor.org/page/info/about/policies/terms.jsp

JSTOR is a not-for-profit service that helps scholars, researchers, and students discover, use, and build upon a wide range of content in a trusted digital archive. We use information technology and tools to increase productivity and facilitate new forms of scholarship. For more information about JSTOR, please contact support@jstor.org. 


\title{
NOTE UPON AN IMPLEMENT OF PALAOLITHIC TYPE FROM THE VICTORIA FALLS, ZAMBESI.
}

\author{
By H. Palfour, M.A.
}

\section{[With Plate XVI.]}

As bearing upon Mr. Lamplugh's interesting paper, the following note may be of interest for the sake of the additional light which is thrown upon the question of the antiquity of the stone implements of the Zarnbesi Valley.

During a week spent at the Victoria Falls in September, 1905, I devoted a portion of my time to searching for Stone Age remains, having been stimulated by the results already achieved by Mr. Molyneux, Mr. Lamplugh, and Colonel Frank Rhodes. Below the Falls, on the plateau which originally formed the bottom of the wide Zambesi Valley, and through which the deep Batoka Gorge has been cut, I found, as they had done, quantities of artificial flakes and rudely worked implements of chalcedony and other stone considerably patinated in most cases. Of these, some were almost as sharp as they were when freshly made, and do not convey the impression of great antiquity; others, on the contrary, show evidence of considerable attrition by rolling, caused, no doul,t, by river action, and appear to have been brought down from a distance by the river, and deposited by it on the spot where they are now found. It seems to me difficult to account otherwise for their abrasion, but if their presence upon the bare rocky expanses some 300 to 400 feet above the present level of the river in the gorge is due to their having been so deposited by the river when it was still flowing at this high level-the same as that of the river above the Falls-the evidence of their great antiquity is manifest. It is not of these that I wish to write, Mr. Lamplugh has already dwelt upon them; I wish particularly to call attention to one specimen which I found on my last day's hunt for implements.

While walking in company with my friend, Colonel H. W. Feilden, along a piece of newly-made road on the left bank immediately above the Falls, I found amongst the coarse stones with which the road was roughly metalled, the implement figured on Plate XVI. It is of chalcedony, $13.7 \mathrm{~cm}$. long, $9.7 \mathrm{~cm}$. wide, $6.6 \mathrm{~cm}$. thick, and weighs just over 26 ounces. As will readily be seen from the illustrations, it is, as regards shape and manufacture, thoroughly palæolithic in type, resembling completely a type of flint implements well known from the River-Drift gravels of Western Europe and England. It has a rounded butt for holding in the hand, and the opposite end has been carefully flaked to produce a cutting edge. As far as 


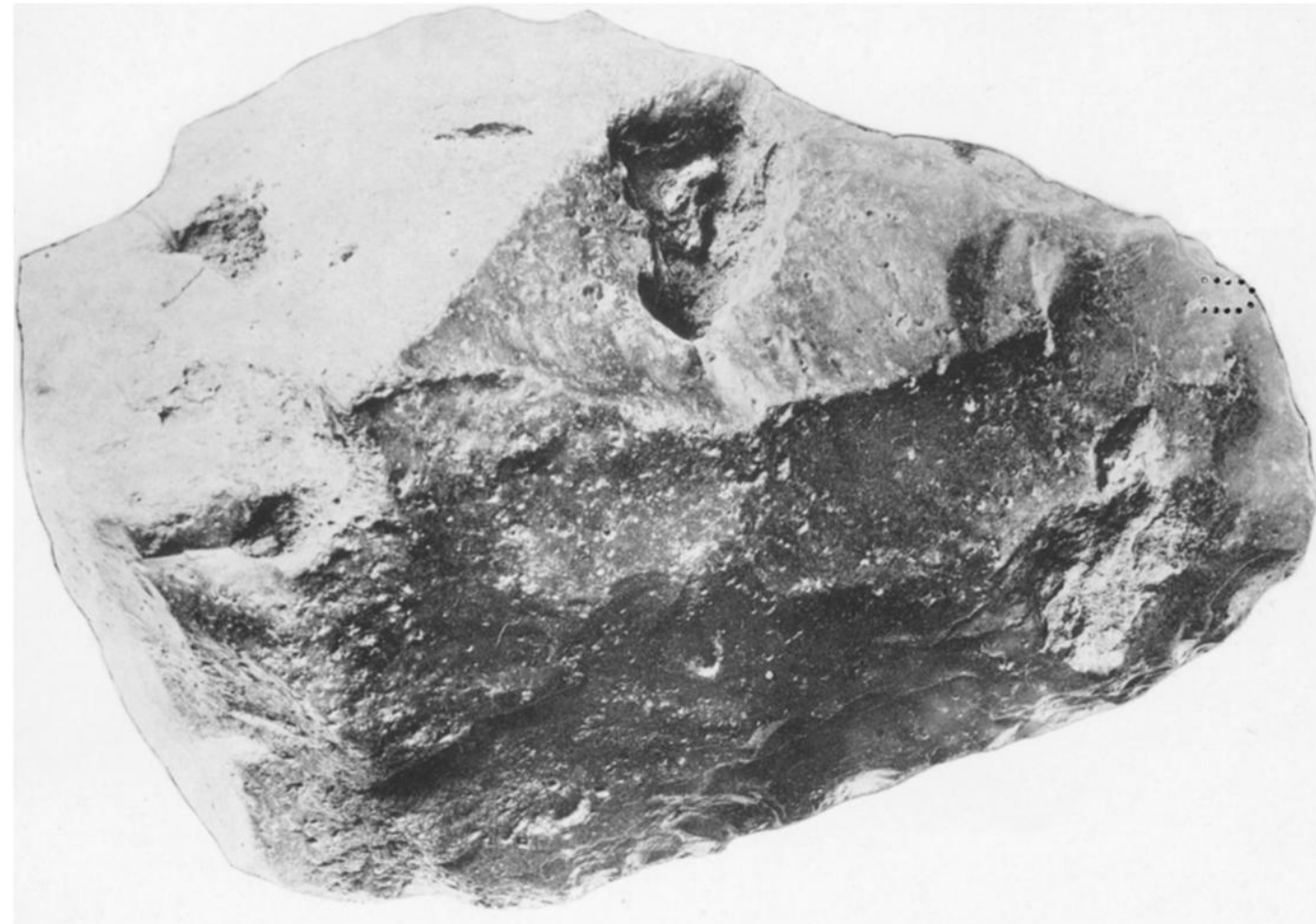

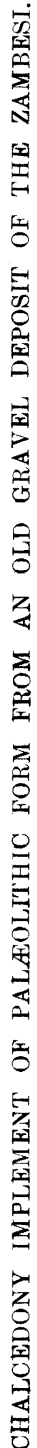


form goes, therefore, this implement is typically palæolithic, and suggests that it belonged to a very rudimentary condition of culture, comparable to that of the River-Drift period of N.E. Europe. It is, further, considerably patinated, and presents a smooth, shiny surface which is probably due to the action of sand during a prolonged period, and there is evidence of long-continued river action in the abrasion of the surface and edges, which has completely dulled the sharpness and definition of the original flaking. The implement has, in fact, the appearance of having been rolled by running water and of having been transported some distance by this agency. The ballast-pit, from which the stones used in metalling the road at this point had been obtained, was within a few yards of the road, and was excavated in an ancient deposit of coarse gravels, formed when the river was running at a level perhaps some 15 to 20 feet above its present level at this point. These gravels consist of coarse water-worn pebbles of various sizes, many of them large and heavy, and include several perfectly spherical nodules as large as a cricket ball. The deposit does not probably exceed about 4 feet in depth, but I was unfortunately unable to take measurements.

We have here then an example of an implement taken from an ancient river deposit of the Zambesi, of which the patination and abraded surface point to a considerable antiquity, and the form and manufacture is pre-eminently characteristic of the implements of the river drift period of Western Europe. The combined evidence seems to point strongly to a strict correspondence of conditions in the two widely separated regions, to a like condition of culture, in both cases of great antiquity. Whether it is legitimate to assign to these Zambesi implements as remote a date as that given on geological evidence to the implements of our own River Drift must be determined by further examination of the older Zambesi deposits, but I cannot doubt that a very long period of time is necessary to account for their characteristics and for the position in which some of them are found. The specimen which I have described appears to me to furnish more complete evidence of high antiquity than any other which I have so far seen from this district, and it is, I think, of interest, in view of the evidence of a very remote Stone Age in South Africa, which is gradually being discovered in other districts. 